American Journal of Remote Sensing
2021; $9(1): 55-64$
http://www.sciencepublishinggroup.com/j/ajrs
doi: 10.11648 /j.ajrs.20210901.17
ISSN: 2328 -5788 (Print); ISSN: $2328-580 \mathrm{X}$ (Online)

\title{
Land Use / Land Cover Change in the Western Highlands of Cameroon: Case of the Sabga-Bamunka Area (1980-2020)
}

\author{
Tankie Quinta Shegwe, Wirsiy Destain Yungsi, Sirri Erika Suh, Tchana Christian Brice, \\ Aloysious Kohtem Lebga*, Takem Mbi Bienvenu Magloire, Chretien Ngouanet
}

National Institute of Cartography, Yaounde, Cameroon

Email address:

quintatankie@yahoo.com (T. Q. Shegwe),wirsiydestain@gmail.com (W. D. Yungsi), sirrierikasuh@gmail.com (S. E. Suh), tchana.christianbrice@yahoo.fr (T. C. Brice), lebga1989gmail.com (A. K. Lebga), takemmbi@yahoo.fr (T. M. B. Magloire), chngouanet@yahoo.fr (C. Ngouanet)

${ }^{*}$ Corresponding author

\section{To cite this article:}

Tankie Quinta Shegwe, Wirsiy Destain Yungsi, Sirri Erika Suh, Tchana Christian Brice, Aloysious Kohtem Lebga, Takem Mbi Bienvenu Magloire, Chretien Ngouanet. Land Use / Land Cover Change in the Western Highlands of Cameroon: Case of the Sabga-Bamunka Area (1980-2020). American Journal of Remote Sensing. Vol. 9, No. 1, 2021, pp. 55-64. doi: 10.11648/j.ajrs.20210901.17

Received: April 14, 2021; Accepted: April 29, 2021; Published: May 8, 2021

\begin{abstract}
Man has greatly influenced the environment through his different activities, technology and dynamism. These modifications are land use/land cover changes. This research describes and analyses the implication of land use dynamics on resources in the Sabga-Bamunka area over time and space from 1980 to 2020. Remote sensing techniques and Geographic Information System were used in describing and analysing land use/cover changes in the Sabga-Bamunka area. Primary data was obtained through field observation in order to confirm observation on satellite imageries. Land use maps were produced using GIS software. Maps were generated to show changes in land use/land cover which were transposed into table and bar graphs to show the magnitude of changes. The analysis of static land use maps of 1980, 2010 and 2020 all showed that there are significant changes observed on forest cover, farmland, grazing land and settlement area. The findings revealed that the study area has experienced a drastic change in land use/land cover during the last forty years. The study area is characterised with decrease in grassland areas, forest and increase in settlement and farmland due to the increasing population which are the main triggering force of land use/land cover changes that has led to the reduction in vegetal cover. Forest decreased from 6568 hectares (26\%) in 1980 to 2842 hectares (10\%) in 2020 indicating a magnitude change of $-3726(-29 \%)$ and grass land decreased from 16434 hectares (64\%) in 1980 to 14585 hectares (53\%) in 2020 that is a magnitude change of $-1849(-14 \%)$. These decreases gave way to settlements and farmland. Therefore, a reduction in the excessive consumption of fuel wood, the practice of eco-forestry, raising of awareness and a dialogue plate-form are amongst the measures recommended to reduce land use/land cover change in the study area.
\end{abstract}

Keywords: Land Use, Land Cover Change, Western Highlands, Sabga-Bamunka, Cameroon

\section{Introduction}

Man's quench for subsistence and habitation has been responsible for the transformation of land use/land cover over the years. Gaining a better understanding of the ways that land cover and land-use practices are evolving is a priority concern of the global research community [42]. Land is very important to mankind's existence and development. Man has used land and its resources to meet needs. Land cover refers to the biophysical characteristics of the earth's surface, including the distribution of vegetation, water, soil, and other physical features of the land While land use refers to the way in which land has been used by humans and their habitat, usually with an emphasis on the functional role of land for economic activities [18, 12-14, 1]. For instance, in terms of urbanisation, a large amount of forest and grassland has been transformed to urban land and other modification are seen in the aspect of archaic agricultural activities, cattle rearing, and deforestation. Land cover (LC) describes the physical state of the land surface; cropland, mountains or forests [20, 22, 26]. Land cover deals with the quantity and type of surface vegetation, water, and earth materials [19, 40]. Meyer [21] defines land use dynamics as conversion of land from one form to another. 
These changes involve modifications, either directly or indirectly on the natural habitat which impacts the environment.

According to [25], since creation mankind has relied on land to sustain his ever-changing needs. Furthermore [29] intimates that change is inevitable and this too applies to land. The earth surface has been significantly transformed through human activities [23]. In developing countries like Cameroon, the population solely depends on natural resource exploitation for livelihood, and with increasingly competing demands for the utilisation, development and sustainable management of land resources [39]. In this process, they have modified and are modifying land in various ways and intensities [7] identified "population pressure, demands for fuel wood and construction material, agricultural expansion, policy and tenure insecurity as the major driving forces behind land use/land cover changes". Some studies suggest that demographic dynamics contribute more than any other process to land cover changes [17]. Others suggested that the superiority of economic factors is the major contributing factor [15].

Nguh [29] observed that "there are few landscapes remaining on the earth's surface that have not been significantly altered or are not gradually being altered by mankind for one reason or the other". In the past two centuries, the impact of human activities on the land has grown enormously, altering entire landscapes, and ultimately impacting the earth's nutrient and hydrological cycles as well as the climate. There are two categories of causes of land use dynamics which include: natural and anthropogenic factors [4]. Human influence on land has resulted to the transformation of the natural land cover into artificial land cover [29]. They further stress that the growing human population has exerted increasing pressure on the landscape as demands multiply for resources such as food, water, shelter and fuel. Land use and land cover in Cameroon have undergone many transformations since independence in 1960 [38]. In Cameroon, agriculture has been tagged the main driver of these changes, which started as far back as the 1970s when the policy of five-year development plan was launched [30, 2,]. It stands out as

a) North West in Cameroon

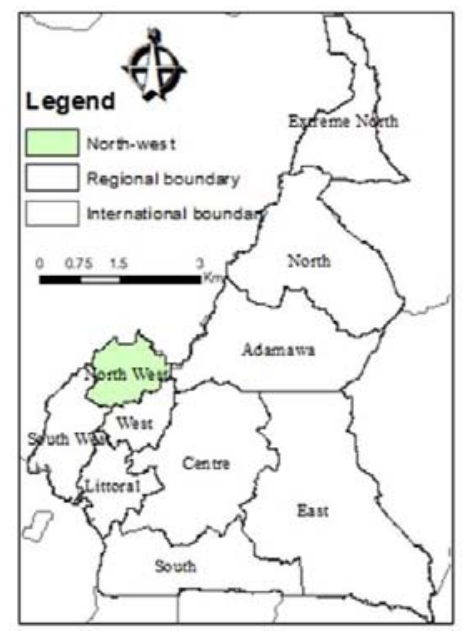

b) Mezam and Ngo Ketunjia in North West Region

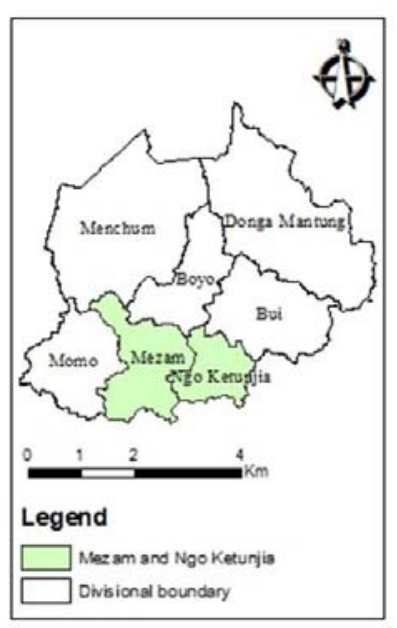

the primary driver of deforestation in most sub-Saharan African countries $(11,6$,). Agricultural activities are the main causes of land degradation, transforming initial forestlands into agrarian lands in addition to fuel wood activities [11, 6,]. Fogwe [7] observed that the major factors influencing land use dynamics include; natural variability, socioeconomic factors, technological factors and globalisation. [10] notice that in the past man depended on gathering and hunting of resources on land, this only led to resource manipulation rather than transformation of the land.

Land degradation, desertification, biodiversity loss, habitat destruction and species transfer are consequences of converting natural land cover [20]. At the local level, changes in the use of land cover affect watershed, modify the surrounding micro climate and influenced runoff, land degradation and biodiversity loss, soil erosion, and sediment loads. Land cover/land use changes have resulted in urban expansion, loss of farmland.

This study seeks to utilize remotely sensed data and GIS tools to analyse the Land use/land cover in Sabga-Bamunka for the purpose of detecting changes in the area by comparing information derived from satellite images. Remotely sensed imageries provide an efficient means of obtaining information on temporal trends and spatial distribution of urban areas needed for understanding, modelling and projecting land changes [5]. Also, remote sensing and GIS provide the possibility to predict the trends in land use/land cover practices in order to make a better concerned projection within a territory $[8,1636]$. Over the years, remote sensing has been used for land use/land cover mapping [9, 35]. Application of remotely sensed data made it possible to study changes in land cover in less time, at low cost and with better accuracy [34]. Remote sensing and Geographic Information System (GIS) provide efficient methods for analysing land use dynamics and tools for land use planning and modelling [33]. Several studies have employed remote sensing data to assess the integrity of green spaces and ecosystem in Lagos [41].

\section{c) Sabga-Bamunka in Mezam and Ngo Ketunjia Division}

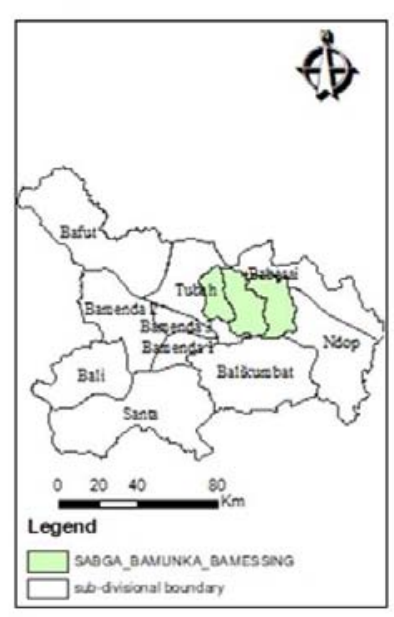


d) RECONNAISSANCE MAP OF SABGA BAMUNKA AREA

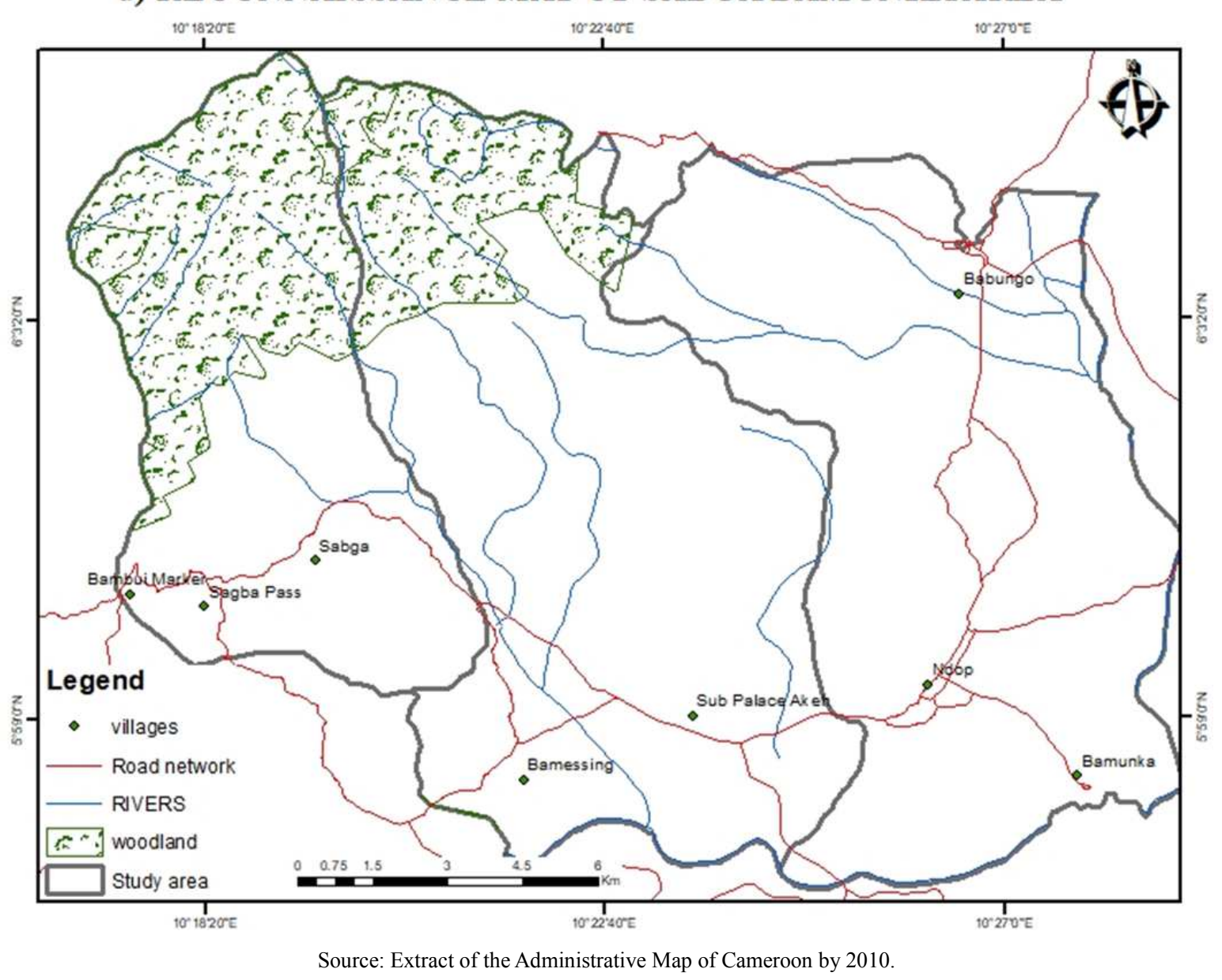

Figure 1. Map of the study area.

\section{Materials and Methods}

\subsection{Case Study Area}

The Sabga-Bamunka area (Figure 1) is located between latitude $6^{\circ} 00^{\prime}$ and $6^{\circ} 6^{\prime}$ North of the equator and between longitudes $10^{\circ} 18^{\prime}$ and $10^{\circ} 24^{\prime}$ East of the Greenwich meridian. This area is found in the North West Region of Cameroon. The area is bordered in the North by the Oku massif, to the west by Mbengwi, to the east by Ngoketunjia and South by Mezam. The area had an estimated population of 62,000 people [3] and it is crossed by many streams and surrounded by hills which favour the rearing of livestock.

\subsection{Data Collection}

This study employed both primary and secondary source of data to describe land use changes over time and space in the Sabga-Bamunka from 1980 to 2020. Information was gotten from primary sources through interviews, administration of questionnaires and handheld Global Positioning System (GPS) for verification of ground control points. A sample size of 200 pastoralists was selected and questionnaires were administered. This was according to the spatial representation of the various grazing land areas within the study area and proportionate number of graziers. Considering the changes that occurred on grazing land, 200 respondents were determined proportionately. Two villages (Bamunka and Sabga) were covered with spectacular focus on pastoralists especially cattle owners and farmers to better assess the elements of grazing land dynamics. In Bamunka, one hundred questionnaires were administered to pastoralists and farmers as well in Sabga. Reconnaissance and field surveys were used to complement the interpretation of satellite imageries. The dynamic nature of land use/land cover processes involving vast areas made traditional methods both costly and inadequate in meeting the spatial and temporal requirements needed in assessing such changes. In order to establish a comprehensive satellite image analysis to determine land cover and land use, information was gotten from Landsat; Thematic Mapper (L4, TM), Enhance Thematic Mapper (ETM), the Operational Land Imager (OLI). A workable procedure was established which entailed the determination of the path and Row. Using the TM, ETM and Operational Land Imager (OLI), the Scene that carries Sabga, Bamessing and Bamuka area could be traced following the path 186 and Row 056 for 2020. Given that each Scene has a surface area of $185 \mathrm{~km} 2$ and that the scene is composed of many pixels with each pixel having a surface area of $30 \mathrm{~m} 2$, was downloaded. 


\subsection{Satellite Image Processing}

The downloaded bands were later combined and our study area was extracted. This was followed by an unsupervised and supervised classification with the aid of ERDAS imagine. Unsupervised classification was carried out for spectral determination whereby cluster zones were created from statistical properties of image pixels. Pixels with similar statistical properties were grouped to form clusters (perform classification of composite image that combine the most useful bands). Five group of clusters were created for Landsat image. This was followed by a field work to verify the characteristics of these features and a supervised classification was carried.

The parametric classification used here was the maximum likelihood algorithm based on probability. This was followed by an accuracy assessment to evaluate the quality of the land cover class and a Kappa coefficient value of 1 (perfect agreement) was gotten. The result of this classification yielded different land cover classes and grouped into categories. This was followed by classification of the surface area of land cover classes followed by a map production and generation of tables for data analysis.

To determine the rate of land use/land cover changes, the magnitude of change, percentage of change and the annual rate of change were calculated. The magnitude of change for each Land use/Land cover (LULC) class was calculated by subtracting the area coverage of the second year from that of the initial year [31] as shown by equation 1 ;

$$
\frac{L C C 1}{T L C} X \frac{100}{1}=\% L C C 1 \text { of } T L C
$$

LCC1b-LCC1a $=$ Rate of change for LCC1 for 40years Where LCC $=$ Land Cover Class TLC $=$ Total Land Cover $\mathrm{LCC} 1 \mathrm{a}=$ Land Cover Class for Built - up area for the year 1980

$\mathrm{LCC} 1 \mathrm{~b}=$ Land Cover Class for Built -up area for the year 2000 2020

LCC1c $=$ Land Cover Class for Built - up area for the year

\section{Result and Discussion}

\subsection{Land Use / Land Cover (LULC) Dynamics from 1980 to 2020}

Land use land cover dynamic is articulated around the interpretation of satellite images produced and the statistical analysis of data on land use/ land cover classes.

\subsubsection{Interpretation of Satellite Images}

The interpretation of land use/land cover classes for three period (1980, 2000 and 2020) shows an unequal distribution of land cover features (Figure 2, Figure 3 and Figure 4).

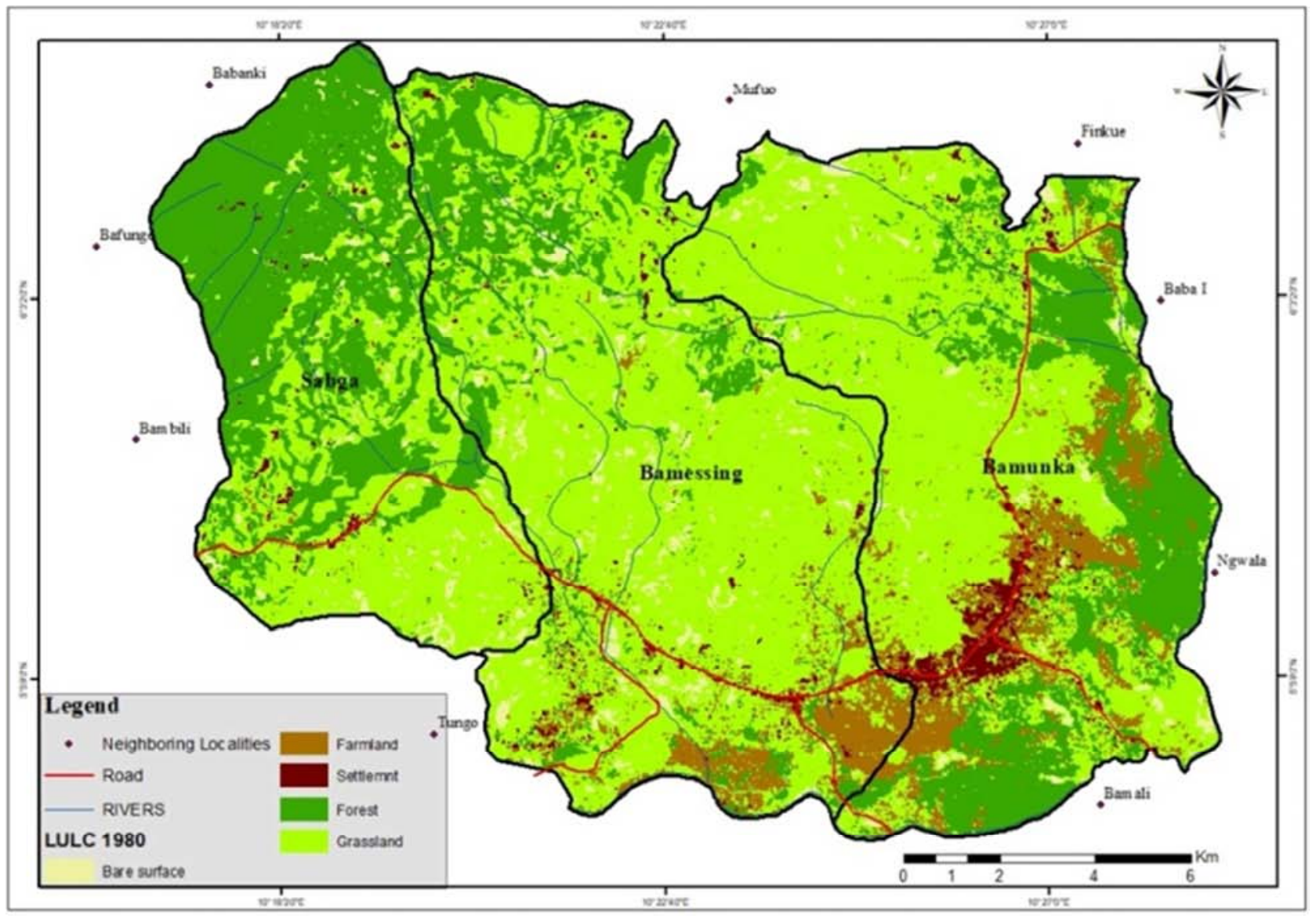

Source: Global Land Cover Facilities/ Landsat MSS, February 1980/ National Institute of Cartography.

Figure 2. The LULC of Sabga-Bamunka Area in 1980. 


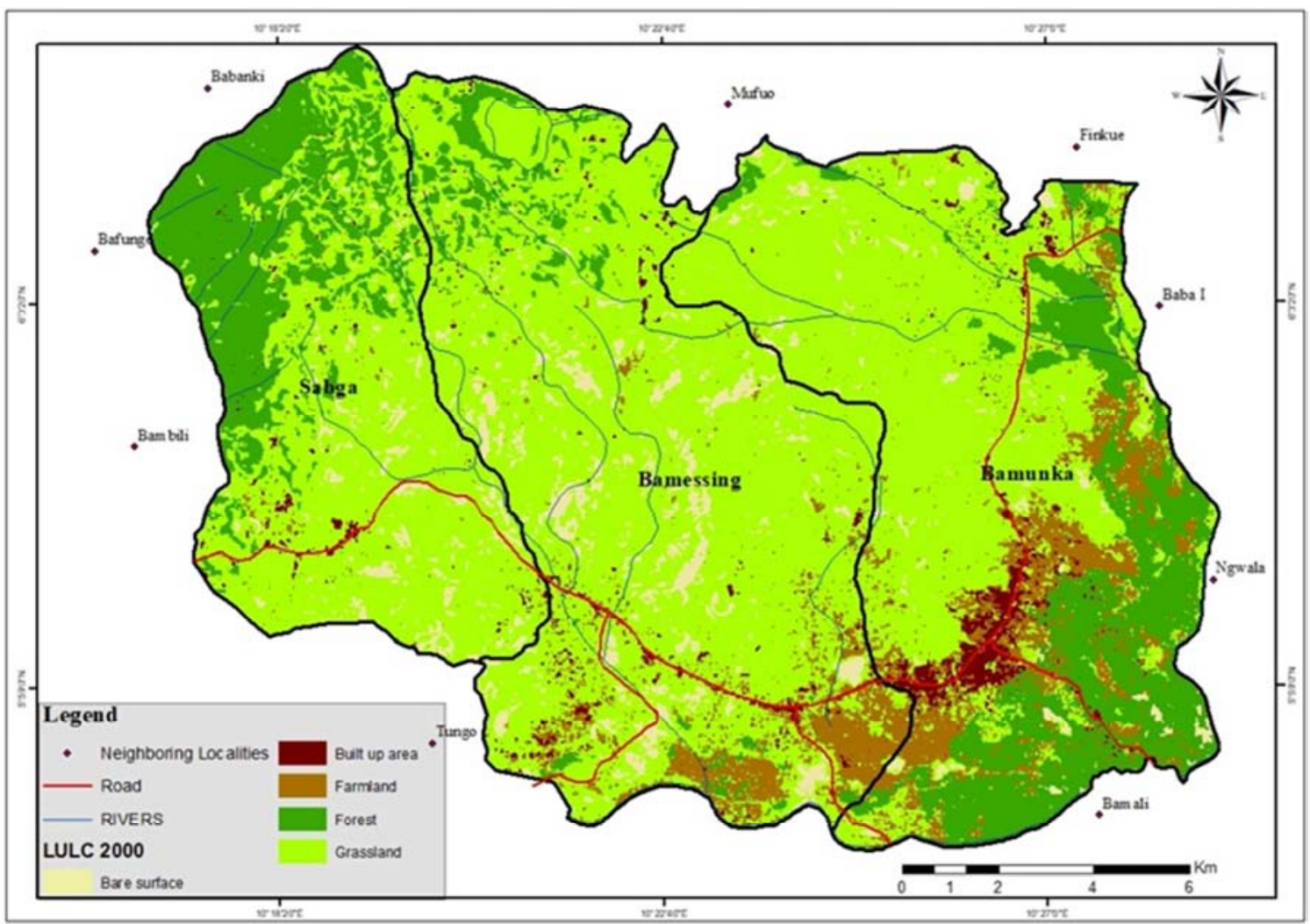

Source: Global Land Cover Facilities/ Landsat ETM+, February 2000/ National Institute of Cartography.

Figure 3. The LULC of Sabga-Bamunka Area in 2000.

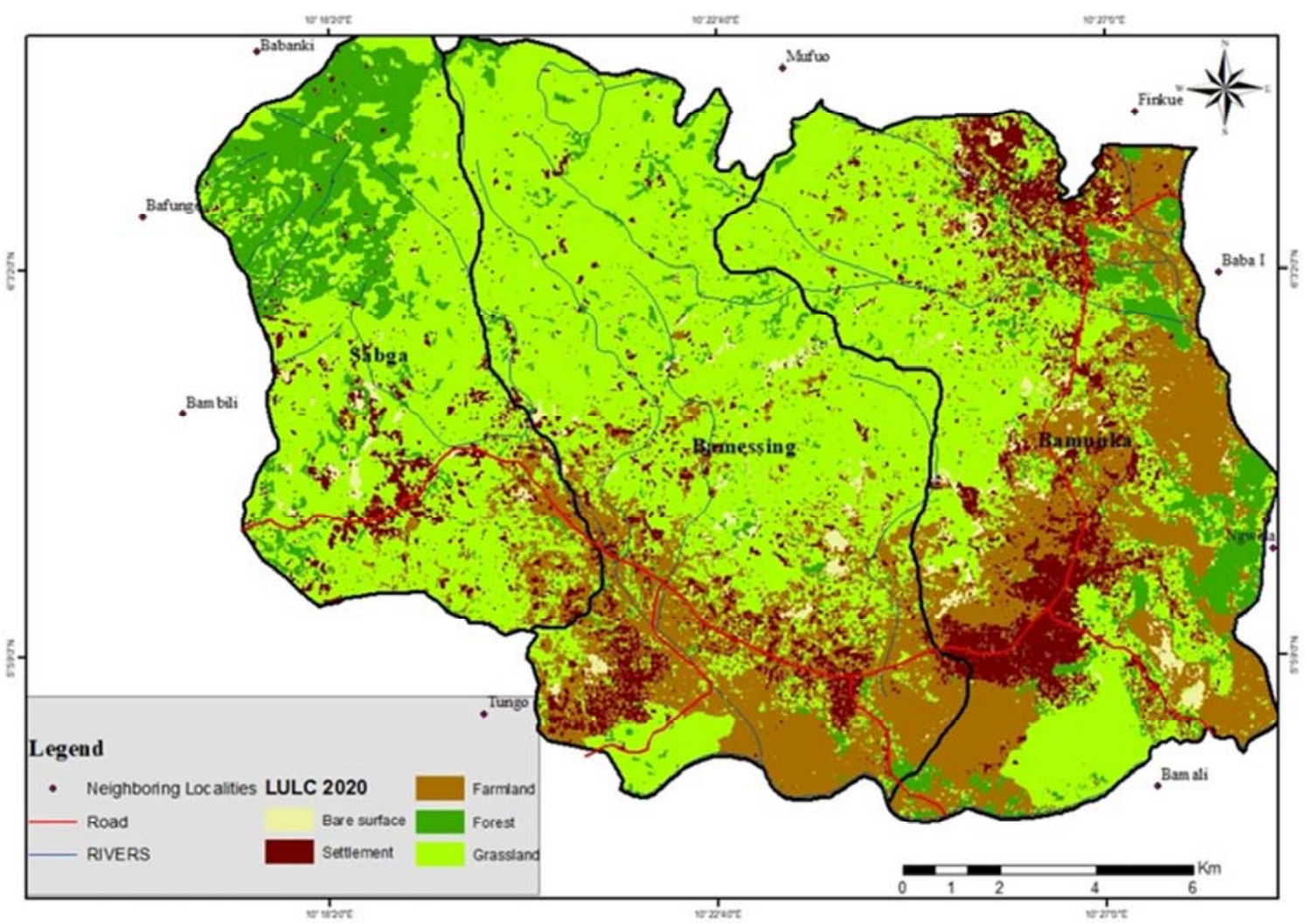

Source: Global Land Cover Facilities/ Landsat ETM+, Operational Land Imager (OLI), February 2020/ National Institute of Cartography.

Figure 4. The LULC of Sabga-Bamunka Area in 2020. 


\subsubsection{Statistical Analysis of Satellite Image Data}

Forest in the 1980s occupied 6568 hectares meanwhile in 2000 it decreased to 5257 hectares and 2842 in 2020 indicating a change of -3726 hectares (between 1980 and 2020). Grassland was 16434 hectares in 1980 and in 2000 it deceased to 15741 hectares and it reduced to 14585 in 2020 there by indicating a change of -1849 hectares. Farmland in the 1980 stood at 1397 hectares but in the year 2000 it increased to 2073 hectares and 5947 in 2020 indicating a change of 4550 hectares. Settlement was 615 hectares in 1980 s and in 2000 increases to 1552 hectares meanwhile it slightly increased to 2398 in 2020 there by indicating a change of 1783 hectares (Table 1 and Figure 3).

Table 1. Magnitude of change from 1980-2020.

\begin{tabular}{|c|c|c|c|c|c|c|c|}
\hline \multirow{8}{*}{$\begin{array}{l}\text { Magnitude of } \\
\text { change in hectares }\end{array}$} & CLASSES OF & YEAR & $\%$ & YEAR & $\%$ & YEAR & \multirow{2}{*}{$\%$ percentage } \\
\hline & LULC & $1980 / 2000$ & percentage & $2000 / 2020$ & percentage & $1980 / 2020$ & \\
\hline & Bare surface & 788 & 18 & 363 & 4 & 1152 & 9 \\
\hline & Settlement & 938 & 21 & 845 & 10 & 1783 & 14 \\
\hline & Farmland & 677 & 15 & 3873 & 45 & 4550 & 35 \\
\hline & forest vegetation & -1311 & -30 & -2415 & -28 & -3726 & -29 \\
\hline & grassland vegetation & -693 & -16 & -1156 & -13 & -1849 & -14 \\
\hline & Total & 4407 & 100 & 8652 & 100 & 13060 & 100 \\
\hline
\end{tabular}

Source: Landsat MSS, 2010/2020.

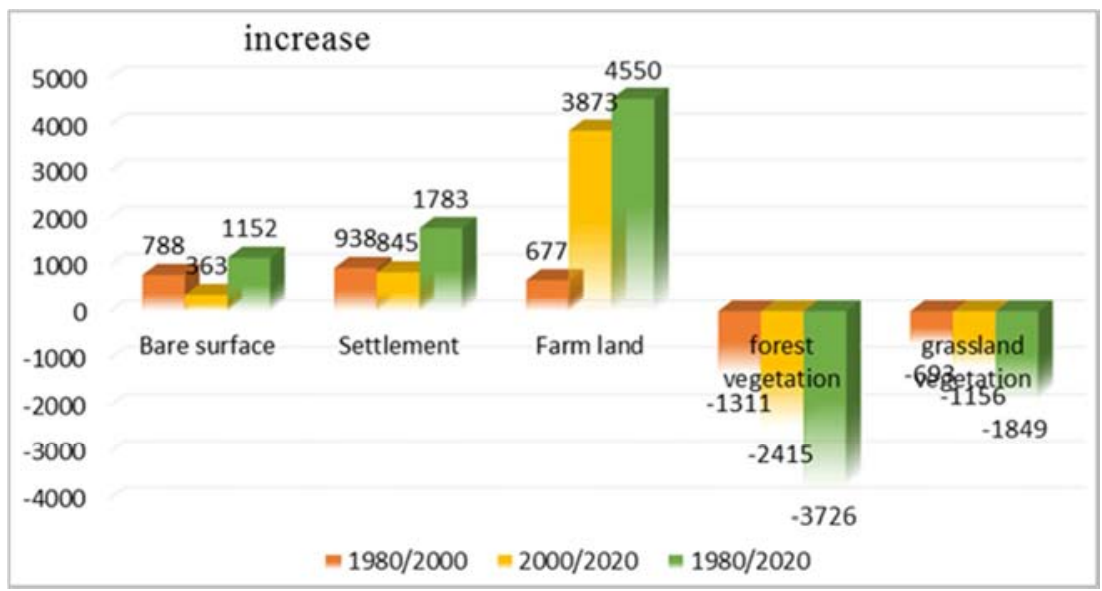

Figure 5. Magnitude of Change for lulc in Sabga-Bamunka from 1980 / 2020.

\subsection{Causes of Land Use/Land Cover (LULC) Dynamics from 1980 to 2020}

\subsubsection{Economic Crises of the 1980s}

In the 1980s farmland dominated the land use/land cover of Sabga-Bamunka. In 2000, Farmland witnessed an increase in surface area of 2073 hectares indicating $8 \%$ of the total surface area and 5947 hectares that is $22 \%$ in 2020 as seen on Table 2 . The causes for this increase in farmland could be attributed to the economic crises of the 1980s because it resulted in rising prices in Cameroon, trade deficit and loss of government revenue. Equally in the face of this crisis, the Cameroon government formulated its plan in which civil servants lost access to subsidised electricity, housing and telephone. Older civil Servants were forced to retirement, salary cut and unemployment was the order of the day, the official working hours was changed, economic mission in foreign embassies from Cameroon were closed, states and parastatal enterprises privatised and government spending was reduced to $18 \%$. As a result, people had no choice to leave urban cities and go back to their villages and look for more lands to cultivate, which Sabga-Bamunka was not left out. The quest for more cultivable lands gradually led to the extension of crop land into grazing and forest area.

Table 2. Area of Land Covers Types in 2000 and 2020.

\begin{tabular}{|c|c|c|c|c|c|c|}
\hline \multirow{2}{*}{ Land cover class } & 1980 & \multirow{2}{*}{$\begin{array}{l}\text { percentage } \\
(\%)\end{array}$} & \multirow{2}{*}{$\begin{array}{l}2000 \\
\text { Area (hectares) } \\
\end{array}$} & \multirow{2}{*}{ percentage $(\%)$} & \multirow{2}{*}{$\begin{array}{l}2020 \\
\text { Area (hectares) }\end{array}$} & \multirow{2}{*}{ Percentage (\%) } \\
\hline & Area (hectares) & & & & & \\
\hline Bare surface & 532 & 2 & 1320 & 5 & 1684 & 6 \\
\hline built up area & 615 & 2 & 1552 & 6 & 2398 & 9 \\
\hline Farm land & 1397 & 6 & 2073 & 8 & 5947 & 22 \\
\hline forest vegetation & 6568 & 26 & 5257 & 20 & 2842 & 10 \\
\hline grassland vegetation & 16434 & 64 & 15741 & 61 & 14585 & 53 \\
\hline
\end{tabular}

Source: Landsat MSS, 2010/2020/ NIC. 


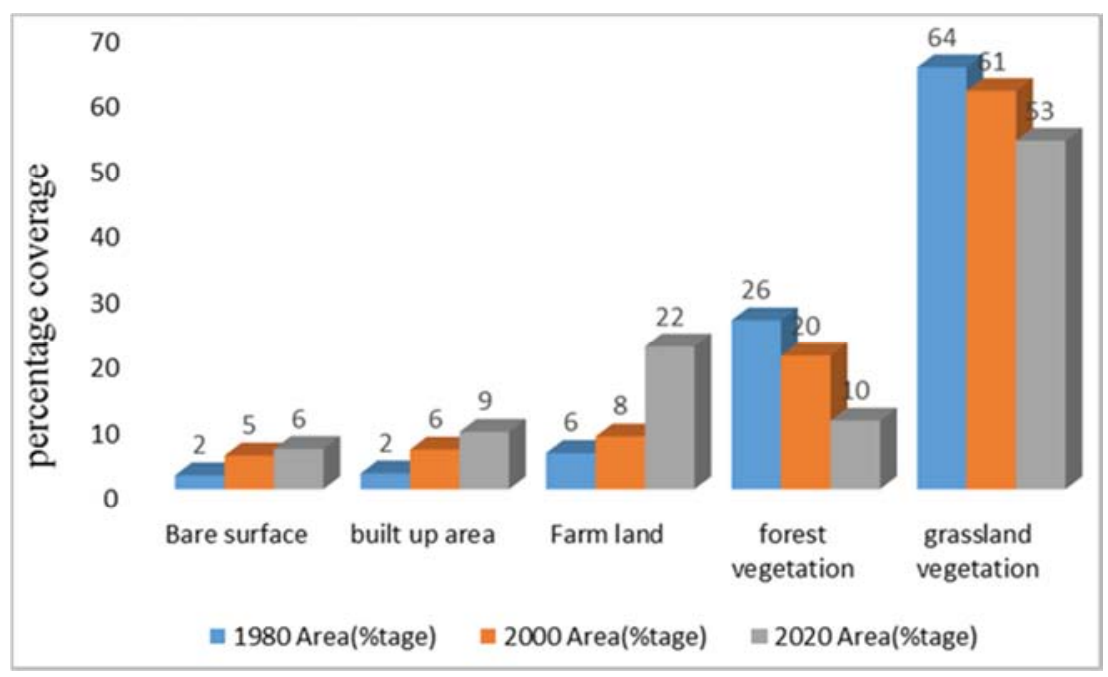

Source; Landsat MSS, 2010/2020.

Figure 1. Land use/cover classes from 1980 to 2020.

\subsubsection{Forest Exploitation}

In 1980 forest occupied $26 \%$ but as years passed, forest reduced gradually. Forest cover dropped to 5257 hectares accounting for $20 \%$ of the total surface area in 2000 and 2842 hectares accounting for $10 \%$ in 2020 while grass land vegetation in $1980 \mathrm{~s}$ occupied 16434 hectares (64\%) meanwhile in 2000 it was $15741(61 \%)$ and 2020 we had $14585(53 \%)$. All these show a decreased in grassland vegetation as seen on table 2 below. The causes for this reduction are linked to the fact that the natural forest and grassland was giving way to agricultural activities like crop cultivation, animal grazing, settlements, as well as the harvesting of fuel wood needed by the inhabitants. It was realised that the actors responsible for these reductions are: the inhabitants of the neighbouring villages and traders in plank, who encroach upon the forest area to practice several activities such as cultivation, wood exploitation for household consumption and for sale. Fuel wood and charcoal constitute the main source of income for approximately $30 \%$ of the local population and $40 \%$ of youths interviewed are directly involved in these activities.

This activity has greatly been encouraged by the existence of a plank market in Mile 12, the presence of several local rice mills specialised in parboiling and packaging of Ndop rice and local furniture workshops in and around this area highly depends on wood. A combination of these activities has led to the changes on land use/land cover types with one gradually replacing the other in terms of surface area from 1980 to 2020. It has been noticed that forest and grassland have decreased more than any other cover type on the one hand while farmland, bare soil and settlement increased, on the other hand. These spatial changes are clearly seen on the figures 2, 3 and 4 above.

\subsubsection{Population Growth}

Settlement in 1980 stood at 615 hectares (2\%) while in 2000 , it increased to 1552 hectares $(6 \%)$ and in 2020 it was 2398 hectares $(9 \%)$. This shows that settlements have increased drastically between 1980 and 2020. The reason for this increase is because population is growing at a very high rate in the area. For instance, in 1976 the total population of the area was 70,138 and in 2005 it was 92,476, [3]. This increase in population meant an increase in land uses and functions with existing land uses being intensified and new land uses for construction. Settlements increased rapidly to meet the need of the rising population.

\subsection{Impacts of Land Use Land Cover Change}

\subsubsection{Farmer-Grazier Conflict}

According to [30], the Northwest Region in general and Sabga- Bamunka area in particular are characterised by a wide range of phenomena and activities that lead to conflicts and ecological changes. Human intervention through farming and grazing naturally brings about dynamics and conflicts. Farmer-grazier conflict is a common phenomenon in the Sabga- Bamunka area. The conflict results from the rapid rate at which grazing areas are changing or degrading. Climate change and increasing in human and animal population have aggravated the pressure [32]. Conflict is often manifested through open violent and ethnic bias because of differences in lifestyle between two communities. Such differences provoked competition over available declining natural resources for grazing, settlement, and farming (Table 3).

Table 3. Perception on Causes and Reasons for Persistence Farmer-Grazier conflict in Sabga-Bamunka Area.

\begin{tabular}{lll}
\hline Reasons and Causes of Farmer- Grazier Conflicts & Respondents & \% of Respondents \\
\hline Increase of crop damage and trace passing into agricultural land & 100 \\
Encroachment into grazing land and blocking of transhumance route by farmer & 60 \\
Inability of the administration and traditional leader to solve farmer-grazier conflicts (corrupt practices) & 36 \\
Total & $31 \%$ & 196 \\
\hline
\end{tabular}


Furthermore, Farmer-grazier conflict in the area often result in open violence [37] and manifested in different ways such as wounding and poisoning of animal by farmers, the chasing of farmers by herdsmen with knives and walking stick used in

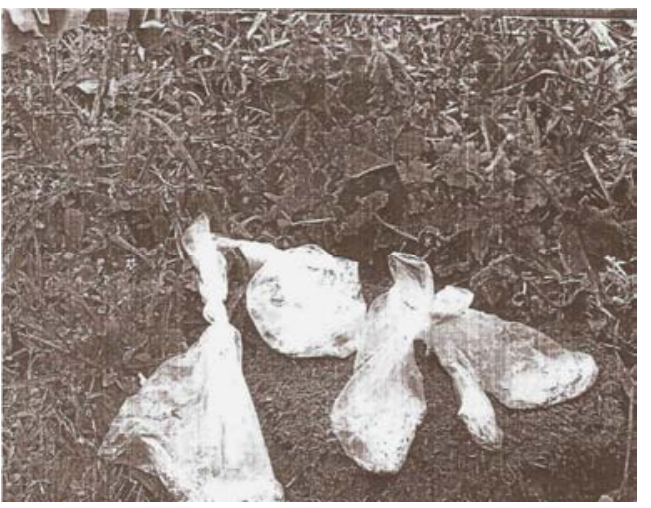

Source: Delegation of Livestock Sabga (1988) [24].

Figure 7. A dead Horse killed by a farmer using salt in Sabga Village.

\subsubsection{Soil Erosion}

The exploitation of forest for domestic, commercial purposes and the repeated passage of cattle over the terrain in some places like around the eastern flanks of Sabga has facilitated the gravitational down slope movement of weathered material. This is because herds of cattle that plough the area repeatedly possess weight which act as overloading at the top of the slope. Consequently, the soil is loosened, and couple with the heavy rainfall around the area, penetration of water gave the lubrication force for slumping leading to the displacement of soil particles.

\section{Recommendation for a Sustainable Landuse Planning in Sabga-Bamunka}

The following recommendations and suggestions based on field investigation are made in order to redress the negative impacts of land use land cover in the Sabga-Bamunka area. These recommendations are reduction in the excessive consumption of fuel wood, practice eco-forestry, raise awareness and a dialogue platform.

\subsection{Reduction in the Excessive Consumption of Fuel Wood}

During field work in the study area, it was realised that $95 \%$ of the household relied on fuel wood to cook. The consistent demand of wood for this purpose has greatly contributed to the reduction and the gradual disappearance of forest vegetation couple with population pressure. That is encouraging the Sabga-Bamunka inhabitants in the consumption of biogas produced using household waste in their homes. However, it is coherent that a reduction in excessive use of wood will enable the forest to regenerate naturally.

\subsection{Practice Eco-forestry}

Eco-forestry is a restorative method of forest management, driving cattle and cutlass. The pictures below show a horse poisoned by a farmer using salt in Sabga. These farmers tight salt in plastic paper and deposited it where cattle graze.

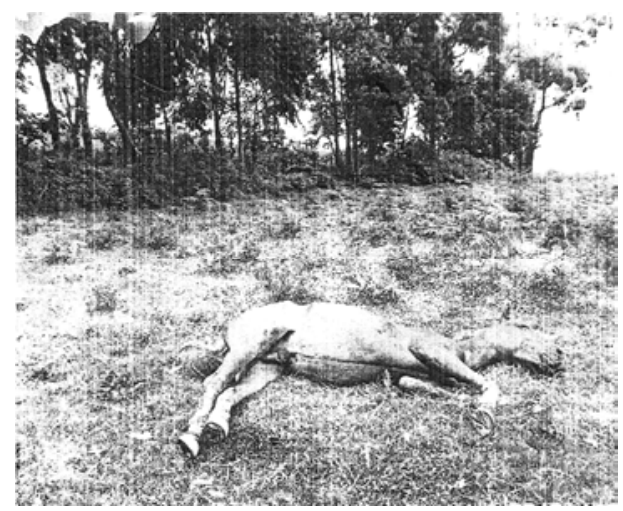

which is not based on economic productivity. In this certain tree are selectively harvested while causing minimal damage to the rest of the forest. The aim of this method is to systematically fell mature trees, while leaving the forest ecosystem relatively unaffected. The adoption of this practice in the Sabga-Bamunka area would reduce the rate of deforestation.

\subsection{Raise Awareness}

Better awareness and education are important amongst farmers and pastoralist in the case of Sabga-Bamunka area. Education of local farmers about optimizing their land management would ensure that less forested area need to be cleared for farming and this would therefore reduce deforestation.

\subsection{Dialogue Platform}

Dialogue platform is a forum where by farmers and graziers are brought together to exchange ideas on issues of farmer-grazier conflicts in order to arrive at peaceful settlement [27]. It can be one of the most efficient ways of handling farmer-grazier conflicts in the area. The forum brings together farmers and graziers to discuss their problems [28]. Graziers consider farmers as partners for access to crop residues after harvest. Farmers also consider graziers as those they can benefit from by having access to cattle dung which improves on soil fertility. Organic crop production could thus be encouraged in Sabga-Bamunka area through this system of integrated crop-livestock farming generated from the dialogue platform.

\section{Conclusion}

The objective of the study was to examine land use/land cover changes and the authors realised Land use dynamics is inevitable and occur on permanent basis. These changes are essential for economic development and social progress, but often come at a substantial cost on the environment and resources. A spatial-temporal analysis of land use/land cover 
has been carried out in Sabga-Bamunka area from 1980 to 2020. The analysis of the land use maps and field observations, all point to the fact that there has been a significant change in land use/cover in this area with forest and grazing land witnessing a steady decline in favour of settlement, bare soil and farmland. This situation has as consequences the destruction of vegetal cover which culminated to soil erosion. These changes in land use/cover have led to environmental and resource issues ranging from loss of biodiversity and impacts such as land use conflicts and haphazard development were also witnessed. This paper can provide substantial source of information to the population of the area and Cameroon at large.

\section{References}

[1] Arsanjani J. J. (2011) Dynamic Land Use / Cover Change Modelling: Geo simulation and Agent-Based Modelling. Vienna: University of Vienna; 2011.

[2] Bamou E, (2007) Distortion to Agricultural incentives in Cameroon, ResearchGate. p42.

[3] BUCREP (2005) Cameroon population census.

[4] De Sherbinin, A. (2002). A CIESIN Thematic Guide to A CIESIN Thematic Guide to Land-Use and Land Use and Land Use and Land-Cover Change (LUCC) Cover Change (LUCC). Center for International Earth Science Information Network (CIESIN).

[5] Elvidge (2007). Remote Sensing. International Journal of Remote Sensing, 28: 12, 2645-2670.

[6] FAO, (2018) The state of the world forest. Forest pathways to sustainable development. Rome 118p.

[7] Fogwe, Z. N., (1997). "Landscape Degradation on the Kom Highland, North West Province, Cameroon) An Environmental Assessment". Thesis of Doctorat de 3eme Cycle in Geogr., Univ. Of Yaounde I, $341 \mathrm{p}$.

[8] Gallardo, M. \& Martínez-Vega, J. (2016). Three decades of land use changes in the region of Madrid and how they relate to territorial planning.

[9] Gautam, N. C., \& Narayanan, L. R. A., (1983). Landsat MSS data for land use/land cover inventory and mapping: A case study of Andhra Pradesh, J. Indian Soc, Remote Sensing, 11 (3), pp 15-28.

[10] Kamusoko, M. Aniya (2006), Land use land use change and landscape fragmentation analyses in Bindura District, Zimbabwe. Willy online library.

[11] Kissinger, G. M. Herold, V. \& De Sy, V. (2012). Drivers of Deforestation and Forest Degradation: A Synthesis Report for REDD + Policymakers. Lexeme Consulting, Vancouver Canada, 46p.

[12] Lambi E. (2006) Land Cover Assessment and Monitoring. Encyclopedia of Analytical Chemistry: John Wiley \& Sons, Ltd; 2006 .

[13] Lambi (2003) Dynamics of land use land cover changes in Tropical regions. Annual review of environment and Resource. vol 28, pp 205-41.
[14] Lambi, E. F. \& Meyfroidt, P. (2011) Global land use change, economic globalization, and the looming land scarcity. PNAS $108(9)$.

[15] Lambin and Geist (2001) The causes of land use and land cover change; Moving beyond the myths. ResearchGate. pp261-269.

[16] Lambin (2011) Land use land cover detection in Saudi Arabian desert Cities of Makkah and Al-Taif using Satellite data. Advances in Remote Sensing vol, 3.

[17] Mather and Needle (2000) The Relationships of Population and Forest Trends. Geographical Journal 166 (1): 2-13.

[18] Mcconnell, W. J. (2015) Land Change: The Merger of Land Cover and Land use Dynamics A2-Wright, James D. International Encyclopedia of the Social \& Behavioral Sciences (Second Edition). Oxford: Elsevier; 2015. p. 220-3.

[19] Meyer (1994) Land cover change and a driving Factors in the Ejin Oasis during 1987-2008. Journal of Desert Research. p35 (3).

[20] Meyer W. B (1995) The Nature and the implications of environmental change past and present land use and land cover in USA. Consequences 1: 1.

[21] Meyer W. B (1996) Human Impact on the Earth. Cambridge University press London.

[22] Meyer, W. B. (1995). Past and present land use and land cover in the USA. Consequences, 1 (1), 25-33.

[23] Millennium Ecosystem Assessment (2005) Ecosystems and Human Well-Being Synthesis. World Resources Institute, Washington, DC, USA.

[24] MINEPIA, (1987-88). Provincial Service of Animal Production and Industries. Annual Report Bamenda.

[25] Molombe J. M (2011) Land Tenure Systems on Urban Growth and Development in the Limbe Municipality. Unpublished M. Sc. Thesis, FSMS, University of Buea.

[26] Moser, S. C. (1996). A partial instructional module on global and regional land use/cover change: assessing the data and searching for general relationships. Geo-Journal, 39 (3), 241-283.

[27] Nchinda, V. (2013). Expert View. 'In Search of Common Ground' for Farmer-Grazier Conflicts in the North West Region of Cameroon. Vol. 4.

[28] Nforya, D. (2020), conflicts and environmental problems affecting cattle grazing and their management strategies in Noni subdivision, Cameroon, Revista Universitară de Sociologie, pp: 34-50.

[29] Nguh, B. S., \& Maluh, N. B. (2017). The implications of land use/cover dynamics on resources development in Tubah sub-division, Cameroon. Journal of the Cameroon Academy of Sciences, 14 (1), 71-85.

[30] Ngwa, N. E. (1989) Cameroon small farmers and agro-pastoral credit. Herder and Herder, New York.

[31] Nkwemoh, A. Wirsiy, D. Y. (2017) Application of Remote sensing and GIS in the evaluation of the Impact of the Lom Pangar Hydro-Electricity Power Dam Project on Vegetation cover. International Journal of Humanities and Social Sciences, pp. 117-134. 
[32] Nkwemoh, C. (1999): "The impact of Agro-pastoral activities on the physical environment Mezam- Ngoketunjia area". University of yaounde1 $289 \mathrm{p}$.

[33] Praveen. k. M., Jayarama, R (2013) Analysis of land use land cover changes using remote sensing data and GIS at an Urban area, Tirupati, India, Scientific world Journal, p 12.

[34] Rawat J. S, Kumar M. (2015). Monitoring land use/cover change using remote sensing and GIS techniques: A case study of Hawalbagh block, district Almora, Uttarakhand, India. The Egyptian Journal of Remote Sensing and Space Science. $\quad 2015 ; \quad 18 \quad$ (1): $\quad 77-84$. https://doi.org/10.1016/j.ejrs.2015.02.002.

[35] Sharma, V. V. L. N., Murali. k, g., Hemamalini, b., \& Nageswararao, k., (2001). Landuse/Landcover Change Detection through Remote Sensing and its Climatic Implications in the Godavari Delta Region, Journal of the Indian Society of Remote Sensing. Vol. 29, No. 1\&2.

[36] Sleeter, B. M., Sohl, T. L., Wilson, T. S., Sleeter, R. R., Soulard, C. E., Bouchard, M. A., Sayler, K. L., Reker, R. R., and Griffith, G. E. (2012) Projected land-use and land-cover change in the Western United States, chap. 6 of Zhu, Zhiliang, and Reed, B. C., (eds.), Baseline and projected future carbon storage and greenhouse-gas fluxes in ecosystems of the Western United States. U. S. Geological Survey Professional Paper 1797, 22 p. (Also available at http://pubs.usgs/gov/pp/1797.).
[37] Tankie Q. S. (2016): Dynamics of Grazing Land and the adaptation of Pastoralist in the Sabga- Bamunka Area (NWR). Master's Thesis, University of Yaounde 1. 150p.

[38] Tchindjang M, Saha F, Voundi E, Mbevo F. P, Ngo M. R, Issan I and Tchoumbou F. S, (2020) Land Use and Land Cover changes in the Centre Region of Cameroon, Preprints, 34p.

[39] Toh, F. A., Angwafo, T., Ndam, L. M. and Antoine, M. Z. (2018) The Socio-Economic Impact of Land Use and Land Cover Change on the Inhabitants of Mount Bambouto Caldera of the Western Highlands of Cameroon. Advances in Remote Sensing, 7, 25-45. https://doi.org/10.4236/ars.2018.71003.

[40] Turner, B. L., Meyer, W. B., \& Skole, D. L. (1993). Global land-use/land-cover change: towards an integrated study. Ambio. Stockholm, 23 (1), 91-95.

[41] Twumasi, Y. A., Merem, E. C., Namwamba, J. B., Mwakimi, O. S., Ayala-Silva, T., Abdollahi, K., Okwemba, R., Lukongo, O. E. B., Akinrinwoye, C. O., Tate, J. and LaCour-Conant, K. (2020) Degradation of Urban Green Spaces in Lagos, Nigeria: Evidence from Satellite and Demographic Data. Advances in Remote Sensing, 9, 33-52. https://doi. org/10.4236/ars.

[42] Turner B L, Moss R H, Skole D L (1993). Relating land use and global land-cover change: A proposal for an IGBP-HDP core project. Report from the IGBP-HDP Working Group on Land-Use/Land-Cover Change. (=IGBP Report 24/HDP Report 5). Stockholm: Royal Swedish Academy of Sciences. 